\title{
Keeping a Household Inventory and Protecting Valuable Records
}

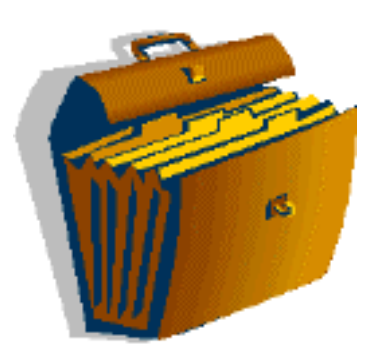

- This publication was written by Regina Fegan and Michael T. Olexa, Food and Resource Economics Department, University of Florida.

- This document, IFAS publication DH0207, was published June 1998, revised May 2003. It is part of The Disaster Handbook, a component of the Comprehensive Disaster Preparedness and Recovery Education Module: General editor: Carol J. Lehtola, Agricultural and Biological Engineering Department, Institute of Food and Agricultural Sciences, University of Florida, Gainesville, Florida 32611.

For information about products and ordering, please visit:

$<$ http://disaster.ifas.ufl.edu>

UF/IFAS Extension publications are

available at the EDIS Web site:

$<$ http://edis.ifas.ufl.edu $>$.

- The Institute of Food and Agricultural Sciences is an equal opportunity / affirmative action employer authorized to provide research, educational information, and other services only to individuals and institutions that function without regard to race, color, sex, age, handicap, or national origin. For information on obtaining other extension publications, contact your county Cooperative Extension Service office. Florida Cooperative Extension

Service / Institute of Food and

Agricultural Sciences / University of

Florida / Christine Taylor Waddill, Dean.
A disaster strikes. Your home and possessions are destroyed. Will you be able to pick up the pieces? You will, if you:

Î Keep and up-to-date household inventory.

I Keep this and other valuable documents in a secure location.

This publication provides details about these two tasks.

\section{Keeping a Household Inventory}

An up-to-date household inventory is a valuable resource. Before a disaster, the inventory will help you determine if you have enough insurance to cover the contents of your home. After the disaster, the inventory will help prove the value of the possessions that are damaged or destroyed for insurance or tax deduction purposes.

An inventory consists of a:

- Description of each item (include model and serial numbers)

- When you bought it

- How much it costs

It is highly recommended to have photos or a video to accompany your inventory.

Do not forget less expensive items, such as towels and clothes. It will be costly to replace them entirely. Be thorough. Do not forget lawn furniture or tools in the garage. Keep the inventory up to date.

There are computer software programs to assist you in this task.
The Disaster Handbook

Institute of Food and Agricultural Sciences

University of Florida
Keeping a Household Inventory and Protecting Valuable Records

Section 2.7 
The University of Illinois Extension Service provides an excellent online guide and relevant forms for conducting a household inventory:

$<$ http://www.ag.uiuc.edu/ vista/abstracts/ahouseinv.html $>$

The Florida Department of Insurance also provides household inventory forms at

$<$ http://www.fldfs.com/Consumers/Guides/HomeChecklist.pdf $>$

\section{Protecting Valuable Records}

The key to a smooth recovery is documentation. Secure your valuable papers in a waterproof, fireproof container.

Table 1 is a list of the valuable papers that need to be in a safe deposit box, especially during a disaster such as a hurricane. Table 2 is a list of valuable papers that need to be in your possession at home at all times in a waterproof, fireproof locked box.

Additional copies of valuable records should be in the care of a lawyer, the administrator of wills, business associates or trusted family members residing outside of your home.

\section{Table 1. Valuable Papers to Keep in Your Safe Deposit Box}

\begin{tabular}{|c|c|}
\hline $\begin{array}{l}\text { Property } \\
\text { ○ Property records } \\
\text { (deeds, titles, leases) } \\
\text { ○ Household inventory } \\
\text { - Home improvement records } \\
\text { - Automobile title and bill of sale } \\
\text { - Copies of insurance policies }\end{array}$ & $\begin{array}{l}\text { Identification } \\
\text { - Social security cards } \\
\text { - Citizenship papers } \\
\text { ○ Passports } \\
\text { - Birth certificates } \\
\text { - Death certificates }\end{array}$ \\
\hline $\begin{array}{l}\text { Financial } \\
\text { o Income tax returns } \\
\text { o Copyrights and patents } \\
\text { ○ Contracts } \\
\text { (including promissory notes) } \\
\text { - Copies of insurance policies } \\
\text { - Certificates for stocks, bonds, etc. } \\
\text { - Important receipts and bills of sale } \\
\text { - Supporting documents for years of } \\
\text { large transactions, unusual losses or } \\
\text { deductions }\end{array}$ & $\begin{array}{l}\text { Other } \\
\text { ○ Divorce decrees } \\
\text { ○ Adoption/Custody papers } \\
\text { - Military service records } \\
\text { - Retirement papers } \\
\text { - Religious records } \\
\text { ○ Copies of your and your partner's } \\
\text { wills } \\
\text { - Trust agreements, living wills, } \\
\text { powers of attorney, and health } \\
\text { care powers of attorney }\end{array}$ \\
\hline
\end{tabular}

The Disaster Handbook Institute of Food and Agricultural Sciences University of Florida
Keeping a Household Inventory and Protecting Valuable Records

Section 2.7

Page 2 


\title{
Table 2. Valuable Papers to Keep at Home in a Waterproof,
} Fire-proof Locked Box

\section{General}

- Safe deposit box key

- Safe deposit records and inventory of items

- List of emergency contacts (doctors, vets, financial advisors, clergy, reputable repair contractors, and family members)

\section{Property \\ $\circ$ Rental property records \\ $\circ$ Guarantees and warranties \\ - Appliance manuals \\ - Copies of insurance policies}

\section{Financial}

- Income tax returns

- Current bank balances

$\circ$ Loan payment books

$\circ$ Employee benefits

- Bank account, loan, credit card, investment account numbers

Identification

- Social security numbers

- Drivers license numbers

- Copies of citizenship papers

- Copies of birth certificates

$\circ$ Copies of marriage certificates

$\circ$ Educational records

\section{Health}

$\circ$ Health records

- Copies of immunization records

- Copies of prescriptions for medicines and eyeglasses

- Copies of veterinary/vaccination records

$\circ$ Health, dental, or prescription insurance cards

\section{Sources for this Publication}

Financial Preparedness (FEMA Publication 291E).

Federal Emergency Management Agency (FEMA and the

American Red Cross. Access on the Web at:

$<$ http://www.fema.gov/pdf/library/prep.pdf $>$

\author{
Household and Personal Property Inventory Book (Publication \\ number C1218) \\ University of Illinois Extension \\ Access on the Web at: \\ $<$ http://www.ag.uiuc.edu/ vista/pdf_pubs/houseinv.pdf
}

The Disaster Handbook

Institute of Food and Agricultural Sciences

University of Florida
Keeping a Household Inventory and Protecting Valuable Records

Section 2.7

Page 3 


\section{Homeowner's Inventory Checklist Florida Department of Insurance Access on the Web at: $<$ http://www.fldfs.com/Consumers/Guides/HomeChecklist.pdf $>$}

This publication is designed to provide accurate, current, and authoritative information on the subject. However, since the laws, regulations, administrative rulings, and court decisions on which it is based are subject to constant revision, portions of this publication could become outdated at any time. This publication is distributed with the understanding that the authors are not engaged in rendering legal advice or opinions, and the information contained herein should not be regarded, or relied upon, as a substitute for legal advice or opinion. For these reasons, the utilization of these materials by any person constitutes an agreement to hold harmless the authors, the Institute of Food and Agricultural Sciences and the University of Florida for any liability claims, damages or expenses that may be incurred by any person as a result of reference to or reliance on the information contained in this fact sheet.

The Disaster Handbook Institute of Food and Agricultural Sciences University of Florida
Keeping a Household Inventory and Protecting Valuable Records

Section 2.7 